\title{
Does Social Insurance Help Secure Property Rights?
}

\author{
Robert MacCulloch \\ STICERD \\ London School of Economics and Political Science
}

DEDPS 31

The Suntory Centre

Suntory and Toyota International Centres for Economics and Related Disciplines

London School of Economics and Political Science

Houghton Street

London WC2A 2AE

September 2001

Tel: (020) 79556674

I give thanks to Tim Besley, Rafael Di Tella, Alan Manning, John McMillan, Andrew Oswald, Steve Pischke and seminar participants at London School of Economics, Warwick University and the Australasian Meeting of the Econometric Society in Auckland for helpful comments. 


\begin{abstract}
This paper develops a simple model to show how social insurance affects the desire to revolt against property rights. It then tests for the effect of social insurance on revolt by introducing a panel data set derived from surveys across over 200,000 randomly sampled individuals from the 1970s to the 1990s. After controlling for the personal characteristics of respondents, country fixed effects, year dummies, as well as country-specific time trends, less people are found to support revolt when the generosity of either the elderly person's social security or unemployment benefits increases. A one standard deviation change in either variable explains approximately one standard deviation of the proportion of people supporting revolt, measured across the countries and years in the sample. The personal characteristic with the largest effect on reducing revolutionary support is being religious.
\end{abstract}

Keywords: Social Insurance, Property Rights, Revolt.

JEL Classification: D23, D31, D74.

Contact address: Robert MacCulloch, STICERD, London School of Economics, Houghton Street, London WC2A 2AE, UK. Email: r.macculloch@1se.ac.uk

(c) The author. All rights reserved. Short sections of text, not to exceed two paragraphs, may be quoted without explicit permission provided that full credit, including (c) notice, is given to the source. 


\section{Introduction}

The existence of social insurance is often justified by economists on the grounds of its risk-management function, the risk that some random turn of events will leave a worker unemployed or elderly people impoverished. However the historical origins of social insurance owed more to the objective of increasing the security of property rights. Cementing these rights lay the cornerstone for the market economies of the future. A frequently cited example is the first mandatory, old-age pension system created in Germany in 1889. Otto von Bismark, "its sponsor and thus the founder of modern old-age social security, was neither a reformer nor particularly liberal. The 'iron-chancellor' advocated social security in the hope of pacifying the proletariat and luring them away from socialism". ${ }^{1}$ I test for the effect of social insurance on rebellion using a survey data set with over 200,000 randomly sampled individuals from the 1970s to the 1990s. Two types of social insurance are studied: social security for elderly people and unemployment insurance. The data also help answer the old question of whether religion is the opium of the masses. The empirics are based on a choice-theoretic model that shows how the results may have fundamental implications for the design of the optimal welfare state.

The paper lies at the junction of two literatures, one on rebellion against property rights and the other on social insurance. The way in which force can be used to serve one's interests has a long and distinguished history in the economics literature. Karl Marx's (1887) Das Kapital opened the question of whether market economies could be sustained or would meet their end in the violent appropriation by workers of capitalists' property. Schelling (1960) studied conflicts between nations and Olson (1965) dealt with problems of collective action and special interest groups. ${ }^{2} \mathrm{~A}$ recent resurgence of attention has seen a number of papers seeking to extend general economic equilibrium to allow for conflict over property rights in models where resources can be allocated

2 See also Haavelmo (1954), Tullock (1974) and Schumpeter (1991). 
between productive and appropriative activities. These include Grossman (1991, 1994), Hirshleifer (1995), Skaperdas (1992) and Grossman and Kim (1995). An equilibrium income distribution arising solely under threats of force, rather than markets, is derived in Usher and Engineer (1987). Roemer (1998) studies the political economy of revolt, showing how the rich may avoid losing wealth to the majority poor if voters have a preference over a non-economic issue, like religion, in a two dimensional voting game. Kuran (1991) and Lohmann (1994) show how small scale protest activity can trigger a cascade of more protests that lead to the incumbent regime's collapse. ${ }^{3}$

Empirical papers on rebellion are less common in economics. Durham et al (1998) use experimental evidence to study when an initially poor party is able to improve its wealth relative to a richer opponent in a game where resources can be divided between productive and appropriative efforts. Benabou (1996) surveys literature on the effect of inequality on political stability. This topic has been of particular interest since political uncertainty may in turn affect investment and growth. ${ }^{4}$ Empirical papers explaining rebellion are more common in political science where economic variables have been added in regressions to test "economic discontent" theories. These include the idea that people feel relatively deprived if they get less than what they think they deserve and the Marxist view that exploitation leads to "immiseration" of the working class. ${ }^{5}$ As an example, Gurr and Moore (1997) study the causes on ethno-political violence in the

\footnotetext{
3 Other papers and books by these authors include Roemer (1985), Hirshleifer (1991), Skaperdas (1991), Grossman (1999) and Garfinkel and Skaperdas (1996). Acemoglu and Robinson (1999) model how political transitions between democracy and autocracy may depend on the level of inequality. A related literature on the economics of crime has its roots in Becker (1968) and Stigler (1970) and another on corruption begins with Rose-Ackerman (1975).

${ }^{4}$ See, for example, Alesina and Perotti (1996), Alesina, Özler, Roubini and Swagel (1996) and Perotti (1996).

5 Although these theories predict a positive effect of income inequality on revolt, empirical studies have given contradictory results (see Gurr (1970), Muller (1985) and Lichbach (1989) for a review). This may be due to biases caused by omitted fixed effects because panel data have not been used and also the difficulty of obtaining good measures of inequality. Another strand of literature seeks to explain revolts by the political processes that provide opportunities for mobilized dissidents to challenge the State (see Tarrow (1989), Francisco (1993)).
} 
1980s. A virtue of the paper is its use of a global data set but the cross-sectional evidence does not control for unobserved fixed effects.

Turning to papers on the economics of social insurance, these have typically ignored the insecurity of property rights. Hubbard and Judd (1987) and Imrohoroglu et al (1995) defend the need for social security for the elderly as insurance against uncertain lifetimes and individual income risk with incomplete markets. Shiller (1998) offers a good description of how social security can help manage risks within and between generations, as well as across nations. Samuelson (1958) and Diamond (1965) motivated its need in a general equilibrium setting as a way of moving the economy from an inefficient equilibrium, characterized by over-accumulation of capital, to an efficient equilibrium by decreasing savings. Whether social security actually does decrease private savings is an old controversy. ${ }^{6}$ Positive theories include Tabellini (1991) and Cooley and Soares (1999). By contrast the literature on unemployment insurance (UI) started by Feldstein (1976), Baily (1978) and Shavell and Weiss (1979) has studied the trade-off between the benefits of more insurance and the potential moral hazard problems arising from more temporary layoffs and less job search. In Shapiro and Stiglitz (1984) higher UI induces greater shirking by workers. Important empirical papers on the adverse incentive effects of UI include Ehrenberg and Oaxaca (1976), Feldstein (1978) and Nickell (1979). ${ }^{7}$ Positive theories include Wright (1986) and Atkinson (1990). ${ }^{8}$ In summary the bulk of the literature has focused on the benefits and costs that social insurance brings society by managing its risks and by affecting behavior such as the desire to save, join the labor force, shirk on the job or search for new work. Property rights have been implicitly assumed secure.

${ }^{6}$ Early papers are Barro (1974) and Feldstein $(1974,1996)$.

7 Atkinson and Micklewright (1991) provides a detailed summary of this literature.

${ }^{8}$ The empirical determinants of unemployment benefits have been tested in Di Tella and MacCulloch (2000). 
This paper begins with a simple model that combines insecurity of property rights in an economy where risk-averse individuals also receive social insurance to protect them against an unlucky turn of events. ' The model shows how the welfare state may be a particularly powerful instrument for crowding out revolutionary efforts in society. The extent of the crowding out becomes an important empirical question and forms the focus of the paper. A large survey data set is used in which people are asked directly whether or not they support revolt. These data form our proxy for the level of rebellion in society. Their use is partly motivated by the great difficulty in obtaining objective measures of this variable. In addition the panel dimension of the data set covering 12 countries across nearly two decades has the advantage of letting us control for unobserved fixed effects. Knowing peoples' personal characteristics also turns out to be key since they mould revolutionary support, in the case of religion, at least as much as the economic variables.

In Section 2 the model is outlined. Section 3 describes the data and strategy used in the empirical part. Section 4 describes the main results. Section 5 provides some extra checks and tests on the results and Section 6 concludes.

\footnotetext{
${ }^{9}$ Sala-i-Martin (1997) shows how social safety nets can be used to bribe poor people out of revolt in a model with risk-neutral individuals. Hence there is no insurance demand for transfers in his economy.
} 


\section{A Simple Model of Revolt}

In this section, a model of rebellion against ownership claims to property is developed. The purpose is simply to outline one mechanism through which potential appropriation of wealth via a revolt may depend on the generosity of the welfare state.

\section{1. The Rebel's Problem}

Assume that individuals have the separable utility function, $U(i, e)=U(i)-c(e)$, where $i$ is income, $e$ is the effort exerted on revolt, $U^{\prime}(i)>0$ and $U^{\prime \prime}(i)<0$. Each person may find him or herself lucky with probability, $1-u$, in which case she earns income, $Y$, or unlucky with probability, $u$, in which case she receives Government transfers of size, $b$, where $b \in[0, Y]$. Without loss of generality, normalize $Y=1$. Let the population be large which means that the proportion of lucky individuals equals $1-u$ and the proportion of unlucky individuals equals $u$. Assume that private insurance markets do not exist. ${ }^{10}$ Having received the Government transfer, an unlucky individual can decide to devote a proportion of his or her spare time to putting effort, $e$, into revolt where $e \in[0,1]$. In the event that the revolt is successful, such a person appropriates pe from the income of lucky people where $p \in[0,1] .^{11}$ The cost of effort to the individual is ce. Assume that the marginal cost of each rebel's efforts, $c$, differs across different rebels. ${ }^{12}$ Let its probability density function be $f(c)$ with support $\left[0, c^{*}\right]$. Assume that the probability of a successful revolt, $\pi$, depends on the average level of rebel effort, $\bar{e}$, exerted across the

\footnotetext{
${ }^{10}$ Empirically, assuming that private markets for UI do not exist seems plausible. Chiu and Karni (1998) state that "unemployment insurance is unique in that unlike other forms of insurance it has never been provided by the private sector" (see also Oswald (1986)). Consequently the assumption of no private UI has been widely made (see, inter alia, Bailey (1978), Azariadis (1975), Wright (1986)). Chiu and Karni (1998) observe that private UI was not even offered when there was no public sector UI. Hence they argue that a fundamental problem, such as moral hazard, is needed to explain the near-universal absence of private UI (rather than just crowding out by the public sector).

11 The assumption of linearity is made for simplicity but can be easily generalized to a more general functional form, $p(e)$ where $p^{\prime}(e)>0$ and $p^{\prime \prime}(e) \leq 0$.

12 The marginal cost of revolt is assumed to be exogenous. Optimal punishment regimes that endogenize this variable have already been studied in the literature, originally by Becker (1968) and Stigler (1970).
} 
whole population: $\pi=\Pi(\bar{e})$ where $\Pi^{\prime}(\bar{e}) \geq 0$ and $\Pi^{\prime \prime}(\bar{e}) \leq 0$. Hence $\pi$ is exogenous for each individual rebel.

The problem for each unlucky individual is to choose his or her effort on rebellion with the objective to maximize expected utility: ${ }^{13}$

$\max _{e} \pi U(b+p e)+(1-\pi) U(b)-c e$

Let the optimal level of effort that solves this problem be called $e(b, c)$. This is a function of the level of transfers chosen by the Government as well as each rebel's marginal cost of effort. The First Order Condition (FOC) is:

$p \pi U^{\prime}(b+p e)-c=0$

Hence the optimal level of effort (for interior solutions) is $e(b, c)=\left[\left(U^{\prime}\right)^{-1}(c / p \pi)-b\right] / p$. Corner solutions also exist where $e(b, c)=0$ or $e(b, c)=1$. No effort is made to rebel by all those individuals for whom $c>p \pi U^{\prime}(b)$. For such people, the marginal cost of their appropriative efforts is always greater than the marginal gain from these efforts. The proportion of unlucky individuals for whom $e(b, c)=0$ is $v(b)=\int_{p \pi U^{\prime}(b)}^{\infty} f(c) d c$. On the other hand, those individuals for whom $c<p \pi U^{\prime}(b+p)$ devote their full available effort on revolt. The proportion of unlucky individuals for whom $e(b, c)=1$ is $w(b)=\int_{0}^{p \pi U^{\prime}(b+p)}{ }_{f(c) d c}$.

\footnotetext{
13 This formulation makes two assumptions. The first is that the proceeds received by an individual in the event of a successful revolt are proportional to the effort that she has contributed to achieving it. The second assumption is that rebels can obtain more income from the lucky people in the event of a successful revolt the higher the average level of effort being exerted across the population to achieve the revolt. In other words the "booty" is not necessarily fixed. If the booty were fixed, we would have to specify the income received by each rebel from appropriate activities as being a function of $e / \bar{e}$ (see, for example, Grossman (1991)).
} 


\section{2. The Equilibrium}

In the equilibrium each rebel chooses effort determined by the solution to problem (1) where the probability of a successful revolt must satisfy:

$\pi=\Pi\left(u \int_{0}^{\infty} e(b, c) f(c) d c\right)$

where $\bar{e}=u \int_{0}^{\infty} e(b, c) f(c) d c$ is the average level of rebel effort in the economy. To characterize the equilibrium we study separately two cases, the first one where $\Pi^{\prime}(\bar{e})=0$ and the second one where $\Pi^{\prime}(\bar{e})>0$. For interior solutions the following results are obtained.

Theorem 1 (One-for-One Crowding Out): If $\Pi^{\prime}(\bar{e})=0$ then increases in Government transfers crowd out the income appropriated in the event of a successful revolt one-forone:

$p e_{b}^{\prime}(b, c)=-1$

Proof: The FOC is $p \pi U^{\prime}(b+p e)-c=0$. Solving for the income appropriated in the event of a successful revolt yields $p e(b, c)=\left(U^{\prime}\right)^{-1}(c / p \pi)-b$. Differentiating with respect to $b$ gives $p e_{b}^{\prime}(b, c)=-1 . \quad \#$

The reason for this result is that the marginal gain from spending effort on revolt is a function of the total income received by each rebel from both the Government and appropriative activities. Hence increases in Government transfers must be offset onefor-one by decreases in income from appropriative activities to keep the marginal gain the same and maintain the equilibrium. 
A rise in Government transfers can also have other effects when corner solutions exist. First, it increases the proportion of individuals who exert no effort to appropriate others' income: $p_{0}^{\prime}(b)=-p \pi U^{\prime \prime}(b) f\left(p \pi U^{\prime}(b)\right)>0$. Second, it decreases the proportion of individuals who devote their full available effort on revolt: $p_{1}^{\prime}(b)=$ $p \pi U^{\prime \prime}(b+p) f\left(p \pi U^{\prime}(b+p)\right)<0$. For the surviving group of full-time rebels, increases in transfers have no effect since both before and after the increase, $e(b, c)=1$.

To study the more difficult second case where $\Pi^{\prime}(\bar{e})>0$, we put a bit more structure on the problem.

Theorem 2 (More than One-for-One Crowding Out): Assume that $\Pi^{\prime}(\bar{e})>0$ and people have the same marginal cost of revolt. Increases in Government transfers that reduce rebel effort crowd out the income appropriated in the event of a successful revolt more than one-for-one:

$p e_{b}^{\prime}(b, c)<-1$

Proof: If people have the same marginal cost of revolt then $\pi=\prod_{\left(u \int_{0}^{\infty} e(b, c) f(c) d c\right)}=\Pi(u e(b, c))$.

In equilibrium the two conditions, $\pi=\Pi(u e(b, c))$ and $p e(b, c)=\left(U^{\prime}\right)^{-1}(c / p \pi)-b$, must both be satisfied. Substituting the former into the latter and differentiating with respect to $b$ gives $p e_{b}{ }^{\prime}(b, c)=-\left(u c / p \pi^{2}\right) \Pi^{\prime}(e) e_{b}{ }^{\prime}(b, c) V^{\prime}(c / p \pi)-1$ where $V=\left(U^{\prime}\right)^{-1}$. But $V^{\prime}(c / p \pi)<0$ since $U($.$) is a concave function, \Pi^{\prime}(\bar{e})>0$ by assumption and $e_{b}^{\prime}(b, c)<0$ when Government transfers reduce rebel effort. Hence $p e_{b}{ }^{\prime}(b, c)<-1$. \#

An increase in Government transfers now has two separate effects. First it increases the total income received by each rebel which reduces the marginal gain from spending 
effort on revolt. A decrease in rebel effort that results in a one-for-one reduction in income from appropriative activities is able to offset this effect (as in the previous case). However there is now a second effect, due to the fall in the average level of rebel effort across the population which reduces the probability of the revolt being successful. This reduces the expected marginal return to each individual from rebel effort and leads to a further reduction in effort and income from appropriative activities. These two effects produce the result that income appropriated in the event of a successful revolt decreases by more than one-for-one when Government transfers increase.

Consequently an important empirical question is the actual extent to which more generous transfers crowd out revolt. The result in Theorem 2 suggests the welfare state's potential of being a particularly powerful policy instrument for this purpose. The following sections of the paper attempt to estimate the size and significance of the effect.

\section{The data}

Our challenge is to obtain a measure of the effort being made to revolt that is also comparable across countries and time so that we can exploit a panel dimension to the data. One approach is to use measures of protests and violent forms of civil disobedience. A disadvantage of such measures is that they may not capture the underlying level of support for revolt and the corresponding effort being made by rebels to effect an alteration of the existing system of property rights and taxation. Another problem is that there are many different such indirect measures which could potentially be used (such as the number of acts of sabotage, rallies and terrorism) making it difficult to choose between them. Events such as political strikes are hard to 
classify. ${ }^{14}$

In this paper we take an alternative approach and use direct evidence from surveys of revolutionary support. In other words we "let the polls decide". In the next sub-section the data are described, as well as some of the advantages and disadvantages of the use of subjective data. Sub-section 3.2. outlines the empirical strategy taken in the paper.

\section{1. Description}

The source of the data on revolt is the Euro-Barometer Survey Series (1976-1990) which interviews a random sample of 200,547 Europeans in 12 nations over a 15 year period. One question asks: "On this card are three basic kinds of attitudes vis-a-vis the society in which we live in. Please choose the one which best describes your own opinion (One Answer Only)". The three relevant response categories are: "The entire way our society is organised must be radically changed by revolutionary action", "Our society must be gradually improved by reforms", and "Our present society must be valiantly defended against all subversive forces" (The "Don't know" and "Not asked in this survey" categories are not included in our data set). The Appendix provides a summary of this survey.

There are advantages and disadvantages to the use of subjective survey data. An advantage is that individual responses give a direct measure of the level of support for revolt that actually exists in nations. It overcomes several of the disadvantages associated with objective measures (like protests) discussed above. One disadvantage is that the responses may be untruthful. ${ }^{15}$ However micro-econometric equations of the

\footnotetext{
14 Francisco (1993) uses person-days of protest per 100,000 persons per week, noting that "most empirical studies of protest and revolution use other measures, especially political deaths".

15 An issue raised in the psychology literature is that subjects' survey responses may be influenced by what they believe to be the socially desirable response. If the social norm is not to support revolt, subjects may bias their response towards maintaining the status quo. Since the first studies in the area, psychologists have found evidence that this concern may be exaggerated (e.g. Rorer (1965), Bradburn (1969)). Moreover at least part of the influence of social norms can be controlled for in the empirical specifications later on.
} 
support for revolt regressed on the respondent's personal characteristics do have a similar structure across nations (see MacCulloch (1999)). For example, in every one of the 12 nations in the Euro-Barometer Survey, being in a lower income quartile monotonically increases the chance of supporting revolt. In 10 of the 12 nations studied, being unemployed increases the chances of supporting revolt. Men are more likely to support revolt whereas married people are less likely to support revolt in all the nations. These results would not be expected if the survey responses were random. ${ }^{16}$

Another disadvantage may be that although a person says they support revolt, they may not actually be exerting costly effort to achieve one. The proxy works to the extent that the proportion of individuals in a country who state they desire revolt is positively correlated with the efforts being devoted to the cause. The survey response categories also force respondents to make a discrete choice (you must either declare yourself in favor of revolt or not) whereas in practice different individuals can spend different levels of continuous effort on revolt. The simplest way to interpret the response choices is to assume that individuals say they support revolt provided they are exerting effort on revolt greater than some cut-off value, $e^{s}$. In other words the unobservable rebel effort variable, $e(b, c)$, from the model in Section 2 can be interpreted as being the underlying continuous variable from which the observable discrete survey choices are generated. The proportion of the population for which $e>e^{S}$ is:

$$
S(b)=u \int_{0}^{p \pi U^{\prime}\left(b+p e^{S}\right)} f(c) d c
$$

\footnotetext{
16 The effect of other personal characteristics is more ambiguous. Whereas a British higher education decreases support for revolt, a French higher education increases it, both significant at the 1 per cent level. Overall, a higher education after leaving school decreases revolutionary support in six countries and increases it in the other six. The effect of personal characteristics on the desire for revolt across the 51,793 individuals from 37 countries sampled in 1981 and 1990 as part of the World Values Survey is similar to the Euro-Barometer Survey results for income, employment status, sex and marital status.
} 
As the generosity of Government transfers increases, the proportion of individuals who say they support revolt varies according to:

$$
S^{\prime}(b)=u p \pi U^{\prime \prime}\left(b+p e^{S}\right) f\left(p \pi U^{\prime}\left(b+p e^{S}\right)\right) \leq 0
$$

It is this number that we seek to estimate in the subsequent regressions.

Table 1.1 shows the proportions of individuals who desire revolutionary action, versus those who do not (i.e. the ones who desire either gradual reforms or the present society valiantly defended) for the entire sample, the unemployed, manual workers, religious persons, partisan self-placement (left or right) and income quartile. There are 200,547 Euro-Barometer survey respondents, covering people living in 12 nations between 1976 and 1990. Of the whole sample, 6.0 per cent desire revolution. Of the sub-sample of unemployed people, 9.9 per cent desire revolt. Of male respondents, 6.8 per cent desire revolt compared with 5.1 per cent of females. As we proceed from the lowest to the highest income quartiles, there is a monotonically decreasing proportion of responses in favour of revolution, the biggest jump occurring between the $2^{\text {nd }}$ and $3^{\text {rd }}$ income quartiles (from 6.6 per cent to 5.7 per cent, respectively). Within each country the highest level of revolutionary support was in Portugal, which fell from 14.3 per cent in 1985 to 6.0 per cent in 1986. After the "Revolution of the Carnations" on 25 April 1974, Portugal experienced extreme political swings and strikes until entry into the European Community in 1986 secured a measure of stability. ${ }^{17}$ The lowest average level of revolutionary support was 2.3 per cent in Denmark. ${ }^{18}$

\footnotetext{
17 The subsequent regression results are unaffected by the omission of Portugal.

18 Although a small number, Kuran (1991) shows how 'revolutionary bandwagons' can lead to small events creating large sudden increases in the scale of revolutionary support. For example if one person has a bad experience that increases his alienation from the State and drives him to revolt, this may trigger another defection from a person who sees that there is now more opposition and fewer hostile State supporters to be faced. This process may generate explosive growth in rebel numbers from an initially small base, until even
} 
Two measures of the generosity of social insurance are used in the subsequent regressions. The first, SOCLAL SECURITY, is the level of transfer payments made by the Government primarily to retired elderly persons as a proportion of GDP. ${ }^{19}$ The second, UNEMPLOYMENT BENEFITS, is the latest summary measure of the parameters of the unemployment benefit system. This measure was compiled by the OECD Jobs Study (1994) and is the pre-tax average of 18 replacement ratios (for two earnings levels, three family situations and three durations of unemployment). ${ }^{20}$ For further information about these variables, see the Data Definitions in the Appendix.

\section{2. Empirical Strategy}

We relate the support for revolt across 12 European countries to the generosity of their social insurance schemes, other macroeconomic variables and several individual characteristics. Formally, linear approximations of equation (6) are estimated. The particular schemes are the social security for elderly people and the unemployment insurance. We take advantage of both the cross-country and time series variation in the generosity of these programs. The probit regressions are of the form:

$$
\begin{aligned}
\text { SUPPORT REVOLT }_{i c t}^{g}= & \alpha^{g} \text { SOCIAL SECURITY }{ }_{c t}+\beta^{g} \text { UNEMPLOYMENT BENEFITS }_{c t} \\
& +\boldsymbol{\gamma}^{g} \text { MACRO }_{c t}+\boldsymbol{\delta}^{g} \text { MICRO }_{i c t}^{g}+\boldsymbol{\eta}_{c}^{g}+\boldsymbol{\mu}_{t}^{g}+\lambda_{c}^{g} t+\boldsymbol{\varepsilon}_{i c t}^{g}
\end{aligned}
$$

people who had previously strongly defended the State join the revolt as they fear hostility from the rebels if they do not.

19 The advantage of using this measure is its high degree of comparability across countries and time, an important feature for our panel data set. On the other hand, measuring social security generosity by the amount of money paid to each retired person suffers from problems that include estimating the payments received on an individual basis as well as converting all the different country measures into a common unit of exchange.

20 These data are an improvement over previous measures used in the literature (e.g. Layard et al (1991)) and begin to address some of the criticisms raised by Atkinson and Micklewright (1991). I am grateful to David Grubb and Pascal Mariana at the OECD for providing me with this data set. 
where SUPPORT REVOLT ${ }_{\text {ict }}^{g}$ is a dummy variable that takes the value 1 when an individual, $i$, who lives in country, $c$, and year, $t$, agrees with the statement that "The entire way our society is organised must be radically changed by revolutionary action". The superscript, $g$, refers to the fact that we consider the whole sample (in which case $g=W$ hole Sample) but we also divide it on the bases of income (in which case $g=$ Rich, Poor), of ideological inclination (in which case $g=$ Right, Left) and of age (in which case $g=$ Persons $<40$ years old, $>40$ years old $)$. The vector $M A C R O_{c t}$ refers to a set of variables aggregated at the country level that may also affect the support for revolt. These include the level of unemployment (Unemployment Rate) and GDP per capita (Output). Summary statistics are reported in Table 1.2.

The vector $M I C R O{ }_{i t t}{ }^{g}$ refers to a set of personal characteristics of the respondents that may affect an individual's support for revolt, including their age, employment status, income, whether they are a manual worker, religious, etc. We also include $\eta_{c}^{g}$ which is a dummy variable for the cross-sectional units (i.e. countries), $\boldsymbol{\mu}_{t}^{g}$ which is a dummy variable for each year, $\lambda_{c}^{g} t$ which is a country-specific time trend and $\boldsymbol{\varepsilon}_{i t{ }^{g}}$ which is an error term (i.i.d.). Robust standard errors are computed where we correct for potential heteroscedasticity and for potential correlation of the error term across observations that are contained within a cross sectional unit in any given year (see Moulton (1986)).

\section{The Relation between Revolt and Social Insurance}

\section{1. The Regression Evidence}

In Table 2 columns (1) to (5) present the results of the probit regressions using several different specifications of equation (8). In column (1) only the personal characteristics of each of the 200,547 individuals surveyed is regressed on their choice of whether not to support revolt. Marginal probabilities are reported. Being unemployed increases an individual's support for revolt by 2.2 percentage points, being male by 1.5 percentage 
points and being a manual worker by 1.2 percentage points. In contrast, a jump from the bottom to the second income quartile drops the support for revolt by 1 percentage point, a jump from the bottom to the third income quartile drops revolutionary support by 1.9 percentage points whereas a jump from the bottom to the top quartile drops it by 2.4 percentage points. Marital status is also important. Being married decreases the support for revolt by 1.1 percentage points and widowhood drops it by 0.7 percentage points. Separation has the opposite effect, increasing revolutionary support by 2.2 percentage points. These effects remain stable across the subsequent regression specifications.

In column (2) the generosity of Social Security is added as an explanatory variable. Its coefficient is negative and significant at the 5 per cent level. Its size, -0.294 , indicates that a one standard deviation rise in Social Security generosity leads to a fall in the support for revolt of 1.4 percentage points $(=-0.294 * 0.046)$. This is equal to 50 per cent of one standard deviation of the proportion of people who support revolt across the countries and years in the sample $(=1.4 / 2.8)$. In column (3) the Unemployment Rate is included as an explanatory variable. This is important for two reasons. First, although the effect of being personally unemployed has already been included in the set of personal characteristics, the unemployment rate may also affect revolutionary support. This could be due to a 'fear of unemployment' effect. Second, the unemployment rate is a control for the state of the economy. The significance of the coefficient on Social Security now rises to 1 per cent. It also becomes more negative, equal to -0.493 . Using this coefficient, a one standard deviation rise in Social Security leads to a fall in the support for revolt of 2.3 percentage points $(=-0.493 * 0.046)$. This is equal to 82 per cent of one standard deviation of the proportion of people who support revolt across the countries and years in the sample $(=2.3 / 2.8)$. The Unemployment Rate has a positive effect, significant at the 5 percent level, on the support for revolt even after controlling for whether or not the respondent has a job. A one standard deviation increase in the 
Unemployment Rate is associated with a rise in the support for revolt equal to 1.1 percentage points $(=0.295 * 0.037)$.

In column (4) Output, measured by GDP per capita at the price levels and exchange rates of 1985 and expressed in US dollars, is added as an additional control for the state of the economy. The coefficient on Social Security equals -0.494 , almost the same as its value in column (3). Once Output is included, the coefficient on Unemployment remains positive but loses its significance. Output has a negative and insignificant effect on the support for revolt in this specification. ${ }^{21}$

Column (5) repeats the specification in column (4) but adds whether or not an individual is religious as a control in the set of personal characteristics. The variable, Religious, takes the value of 1 when an individual identifies him or herself as belonging to a religion and 0 otherwise. The number of observations drops to 95,035 due to limited availability of this variable. The coefficient on Social Security increases (in absolute size) to -0.720 . Now a one standard deviation rise in this variable leads to a fall in the support for revolt of 3.3 percentage points $(=-0.720 * 0.046)$. This is equal to 1.2 times one standard deviation of the proportion of people who support revolt across the countries and years in the sample $(=3.3 / 2.8)$.

Being religious lowers the probability that the average individual supports revolt by 5.3 percentage points, significant at the 1 percent level. This is the biggest effect out of all the personal characteristics. It is, for example, 2.9 times the size of the effect of being unemployed $(=5.3 / 1.8)$ and 2.2 times the size of the effect of jumping from the bottom to the top income quartile (=5.3/2.4). The coefficient on Religious allows us to calculate a marginal rate of substitution between the generosity of social security and religion, holding the support for revolt constant. If an individual loses religion it would require

${ }^{21}$ The correlation coefficient between Output and Unemployment is equal to -0.21 (as expected by Okun's Law). 
an increase of 7.4 percentage points in Social Security to keep his level of revolutionary support the same $(=0.053 / 0.720)$. This is equal to 1.6 times one standard deviation in the Social Security variable $(=0.074 / 0.046)$.

In Table 3 columns (1) to (5) test for whether the generosity of Unemployment Benefits, in addition to Social Security, affects the support for revolt. The individual controls in the following regressions are not reported because their coefficients change very little (they are often exactly the same as the ones reported in Table 4.1). In column (1) more generous Unemployment Benefits decrease support for revolt at the 1 percent level. The coefficient equals -0.187, implying that a one standard deviation increase in Unemployment Benefits decreases the support for revolt by 3.1 percentage points ($0.187 * 0.166)$. This is equal to 1.1 times one standard deviation of the proportion of people who support revolt across the countries and years in the sample $(=3.1 / 2.8)$. Columns (2) and (3) show that the effect is robust to the inclusion of the other macroeconomic variables, Unemployment Rate and Output.

In columns (4) and (5) the Social Security variable is added. Both our measures of social insurance retain their signs, significance levels and magnitudes in these two regressions. In column (4) the Unemployment Rate has a positive effect on revolt, significant at the 2 per cent level. However once we add a control for Output in column (5) it loses this effect. It is now more Output that reduces the support for revolt, significant at the 10 percent level. A one standard deviation increase in Social Security is expected to lower support for revolt by 2.5 percentage points $(=-0.554 * 0.046)$. A one standard deviation increase in Unemployment Benefits is expected to lower it by 4.2 percentage points (=$0.254 * 0.166)$. These numbers represent 0.9 times and 1.5 times one standard deviation of the proportion of people who support revolt across the countries and years in the 
sample, respectively $(=2.5 / 2.8$ and $4.2 / 2.8)$.

\section{2. Discussion}

The significant and sizable negative coefficients on the Social Security and Unemployment Benefits variables in all the regressions explaining revolt in Tables 2 and 3 suggest that there is a role for Government transfers to 'buy out' threats to property rights. Of course the cost of this policy choice must be traded off against the cost of other choices available to Governments to quell revolt, such as spending on the military, national guard and police, or greater democratization

The large negative coefficient on Religious in column (5) of Table 2, compared to the other personal characteristics, implies that more religiosity may also affect the Government's optimal social welfare policy. If religion makes it more morally costly for an individual to exert effort on revolt then we could think of this as making the marginal cost of such effort, $c$, higher (in terms of the model in Section 2). This lowers the optimal level of rebel effort and could allow the Government to cut the level of social insurance without increasing the chances of revolt. When such a policy implies lower taxes for the higher income individuals, this result could help explain partisan policy differences. If right-wing parties weight the interests of the rich more highly than the poor compared to left-wing parties, then an optimal mix of policies for the right would include promoting a more religious society together with a less generous welfare state compared to the left. ${ }^{22}$

22 In Roemer's (1998) formal model of political competition, the left party may be forced into more conservative policies to win power when voters have preferences given by a joint probability distribution over tax-religion policy space. This occurs because the median poor voter, who would support the left party to redistribute wealth from rich people if only money mattered, may not vote left once religion becomes a salient issue. 


\section{Further Checks and Tests on the Results}

\section{1. Omitted Variable Bias}

There exists the possibility of an omitted variable in equation (8) being correlated with the included measures of social insurance. In terms of the model in Section 2, a drop in the cost of rebel effort due to an improvement in offensive technology would make it easier for people to challenge the existing allocation of property rights. If the Government responded by increasing the generosity of its transfers there would exist an omitted variable bias. Consequently we may expect to observe a positive correlation between our measures of revolt and social insurance if the cost structure is changing and welfare policy is endogenous. ${ }^{23}$ Whether civil disorder induces changes in welfare policies is a subject of continuing debate in political science, starting with Piven and Cloward (1971). There are a number of related examples in the economics literature. In Grossman (1994) land reform that reduces inequality in the distribution of land ownership can be an optimal response to the threat of extralegal appropriation of the landed class' income. North and Weingast (1989) describe how, after the Glorious Revolution of 1688 in England, the winners (the Whigs) sought to redesign government institutions to avoid future revolt. Acemoglu and Robinson (2000) argue that political elites extended voting rights to prevent widespread social unrest and revolution.

To attempt to take account of this possibility, Instrumental Variables (I.V.) using Two Stage Least Squares estimation is employed. Table 4 re-estimates six of the previous specifications but where both measures of social insurance have been instrumented. ${ }^{24}$

\footnotetext{
${ }^{23}$ This would mean that the estimations based on equation (8) are underestimating the true size of the negative effect of social insurance on revolt. For evidence on the endogeneity of social security, see Tabellini (1990), and for unemployment benefits, see Di Tella and MacCulloch (2000).

${ }^{24}$ To do the Two Stage Least Squares regressions, we first ran probit regressions of the support for revolt on the set of personal characteristics listed in Table 4.1 separately for each country. The coefficients on the year dummies in these regressions were subsequently used as the dependent variable in 2SLS regressions in which Social Security and Unemployment Benefits were instrumented.
} 
Columns (1) and (2) repeat the specifications in columns (3) and (4) of Table 2, but using the proportion of elderly people (over the age of 65) as an instrument for Social Security. ${ }^{25}$ In both these I.V. regressions, the coefficient on Social Security retains its significance at the 1 percent level and becomes more negative. The coefficient of the Unemployment Rate becomes both more positive and significant. Columns (3) and (4) repeat the specifications in columns (2) and (3) of Table 3 but use the level and lag of openness (imports over GDP) as an instrument for Unemployment Benefits. ${ }^{26}$ The coefficient on benefits is now more negative than in the previous regressions, although the significance level drops to 10 per cent.

The last two columns in Table 4 report more general specifications in which both Social Security and Unemployment Benefits are instrumented using the proportion of elderly people, openness and an index of the country-specific oil price (defined as the price of oil converted into local currency and standardized to equal 1 across all countries in 1975). In column (5) the coefficient on Social Security is 1.3 times more negative than its value in the corresponding specification in column (4) of Table $3(=0.702 / 0.548)$ whereas the coefficient on Unemployment Benefits is 1.9 times more negative $(=0.384 / 0.207)$. The significance levels of these variables fall to 10 percent and 5 percent, respectively. Although the Unemployment Rate has a positive effect on revolt in this regression, its significance disappears in the toughest test in column (6) where it becomes Output that has a negative effect (at the 10 per cent level). After controlling for both these variables, the coefficients on Social Security and Unemployment Benefits maintain their size although the larger standard error on the latter drops its significance below conventional levels.

\footnotetext{
25 Tabellini (1990) provides evidence that the generosity of social security is increasing with the proportion of the population over the age of 65 and with the level of (pre-tax) income inequality, as predicted by his positive theory.

26 The level of openness has been used as a proxy for an exogenous measure of risk to instrument the size of government in Rodrik (1998) and unemployment benefits in Di Tella and MacCulloch (2000).
} 


\section{2. Different Sub-groups and Adding More Controls}

In Table 5 columns (1) and (2) compare how the determinants of revolt differ depending on whether a person identifies himself as supporting a left versus a rightwing political party. The differences appear striking. None of the four explanatory variables are significant in column (1) for the Right. On the other hand all except for Unemployment Rate are significant with the expected signs in column (2) for the Left. The coefficients on both Social Security and Unemployment Benefits are more negative for the Left than the Right, although it is not possible to statistically reject the null hypothesis that they are the same comparing across these two groups. Higher Output affects the support for revolt more negatively for the Left than the Right, at the 6 per cent level of significance.

Columns (3) and (4) compare how the determinants of revolt differ depending on whether a person is Rich (i.e. lies in the top half on the income distribution) or is Poor (i.e. lies in the bottom half). Whereas higher Output lowers the support for revolt amongst the Poor at the 5 per cent level, the effect is not significant for the Rich. The social insurance variables both have negative coefficients, at the 1 per cent level of significance, for the two income groups. There is some (weak) evidence that Unemployment Benefits reduce the support for revolt more for the Poor than the Rich, whereas Social Security reduces it more for the Rich than the Poor.

As a further test of the robustness of the results, controls for three additional variables

are included in columns (5) and (6). Government Consumption is added in column (5) to check that it is not higher Government spending on goods and services, rather than transfer payments, driving the results. The coefficient on Government Consumption is negative but insignificant whereas the ones on Social Security and Unemployment Benefits have similar size and significance levels to the comparable specification in column (5) 
of Table 3.

In column (6) two more variables are added, Right Wing and Military. The former measures the extent to which the political preferences in a country lean towards the right. It is similar to the indices used by political scientists to indicate the left/right position of Government, and is constructed in two steps (see, for example, Hicks and Swank (1992)). In the first step, we collect the number of votes received by each party participating in cabinet and express them as a percentage of the total votes received by all parties with cabinet representation. In the second step, this percentage of support is multiplied by a left/right political scale (from Castles and Mair (1984)) and summed across all parties to give a continuous variable. Military is defined as spending on the military as a fraction of GDP.

The reason for including Right Wing is the possibility that a set of policies may be undertaken by a partisan political party that affect the support for revolt, in addition to ones relating to the level of transfers to the elderly and the unemployed. For example, a party may wish to cut transfers but also reform labor market flexibility, making it easier to hire and fire workers. Including Right Wing is a way to control for the effect of these additional policies in a single variable. The coefficient on Right Wing is positive but not significant at conventional levels. ${ }^{27}$ Since the degree of repression is also a possible determinant of revolt a proxy, Military, was also included in this regression. ${ }^{28}$ It has a

\footnotetext{
27 The results change slightly if Right Wing is measured as a dummy variable taking the value 1 when a party categorized by political scientists as being "right-wing" is in power (from Alesina and Roubini (1992)). With this alternative definition, the coefficient is positive and significant at the 10 percent level but the size of the effect is small. A change from a left to a right party adds 0.5 percentage points onto revolutionary support, or 18 percent of one standard deviation of the proportion of people supporting revolt across the countries and years in the sample.

28 In Grossman's (1991) model of insurrection, more soldiers decrease the amount of time spent on insurrection and consequently its probability of success. In the political science literature, military repression has been argued to have ambiguous effects on rebellion (see, inter alia, Tilly (1978), Lichbach (1987), Gurr and Moore (1997)).
} 
negative but insignificant effect on the support for revolt. Social Security and Unemployment Benefits again retain the size and significance of their coefficients. Further specifications were also tried, including adding the inflation rate, which had a positive but insignificant effect on revolt.

\section{Conclusion}

The security of property rights lies at the heart of market economies. However obtaining precise estimates of the determinants of the security of property rights has proved difficult. The recent release of large-scale data sets that survey levels of support for revolt in nations has made this task easier. In particular they now allow us to answer some of the oldest questions in this field. Does the level of social insurance reduce the chance of revolt? Is religion the opium of the masses?

This paper first presents examples in a simple model of revolt that show us how the welfare state may be used as a particularly powerful policy instrument for crowding out revolutionary efforts in society. The extent of the crowding out becomes an important empirical question and forms the subsequent focus of the paper. The findings are:

1. Controlling for the personal characteristics of the respondents, country fixed effects, year dummies and country-specific time trends, less people support revolt when the generosity of either the elderly person's social security or unemployment benefits increases. These effects are both significant at the 1 percent level and are of sizeable magnitude. A one standard deviation increase in Social Security (equivalent to increasing spending on the elderly as a fraction of GDP by 4.6 percentage points) lowers the support for revolt by 2.5 percentage points. A one standard deviation increase in Unemployment Benefits (equivalent to increasing the replacement rate by 16.6 percentage points) lowers the support for revolt by 4.2 percentage points. These numbers represent 0.9 times and 1.5 times one standard deviation of the 
proportion of people who support revolt across the countries and years in the sample, respectively.

2. The negative effects of social insurance on revolt are concentrated in the group of individuals identifying themselves as supporting left political parties, but not right parties.

3. The personal characteristic with the largest (absolute) size of effect on revolt is being religious. It lowers the chance a person wants revolt by 5.3 percentage points. Being unemployed, a manual worker or male increases revolutionary support. As one goes up the income quartiles, there is a monotonically decreasing chance of a person wanting revolt.

As a result the optimal design of the welfare state should probably take account of its potential to 'buy out' revolt. It seems that Otto von Bismark got it right in 1889 when he set up the first social security system to pacify the left-wingers of his times. The results also suggest that a less religious nation may need to offer a more generous level of social insurance in order to keep the level of support for revolt constant. This could help explain partisan divisions in which political parties that promote a smaller welfare state sometimes also encourage more religious values. Karl Marx's famous quote from 1844 on religion being the opium of the masses has a strong empirical basis. 


\section{References}

Acemoglu, D. and J. Robinson (1999) “A Theory of Political Transitions", mimeo, MIT.

Alesina, A. and R. Perotti (1996) "Income Distribution, Political Instability, and Investment”, European Economic Review 40(6): 1203-1228.

Alesina, A. and N. Roubini (1992) "Political Cycles in OECD Economies", Review of Economic Studies, 59: 663-688.

Alesina, A., S. Özler, N. Roubini and P. Swagel (1996) "Political Instability and Economic Growth", Journal of Economic Growth 1(June): 189-211.

Atkinson, A. (1990) "Income Maintenance for the Unemployed in Britain and the Response to High Unemployment", Ethics, 100: 569-85.

Atkinson, A. and J. Micklewright (1991) "Unemployment Compensation and Labour Market Transitions: A Critical Review”, Journal of Economic Literature, 29: 1679-1727.

Azariadis, C. (1975) "Implicit Contracts and Underemployment Equilibria", Journal of Political Economy, 83 (December): 1183-1202.

Baily, M. (1978) "Some Aspects of Optimal Unemployment Insurance", Journal of Public Economics, 10(3): 379-402.

Barro, R. (1974) “Are Government Bonds Net Wealth?”, Journal of Political Economy, 82 (November/December): 1095-1117.

Benabou, R. (1996) "Inequality and Growth", in B. Bernanke and J. Rotemberg (eds.), NBER Macroeconomics Annual, MIT Press, Cambridge: 11-92.

Besley, T. and J. McLaren (1993) "Taxes and Bribery: The Role of Wage Incentives", The Economic Journal, 103 (January): 119-141.

Bradburn, N. (1969) The Structure of Psychological Well-Being, Chicago: Aldine Publishing.

Carter, M. and W. Shipman (1997) Promises to Keep, Washington Regenery Publishing.

Castles, F. and P. Mair (1984) "Left-Right Political Scales: Some Expert Judgements", European Journal of Political Research, 12: 73-88. 
Chiu, W. and E. Karni (1998) "Endogenous Adverse Selection and Unemployment Insurance", Journal of Political Economy, 106(4): 806-827.

Cooley, T. and J. Soares (1999) "A Positive Theory of Social Security Based on Reputation”, Journal of Political Economy, 107 (1): 135-160.

Diamond, P. (1965) "National Debt in a Neoclassical Growth Model", American Economic Review, 55 (December): 1126-1150.

Di Tella, R. and R. MacCulloch (1997) "Informal Family Insurance and the Design of the Welfare State", The Economic Journal (forthcoming).

Di Tella, R. and R. MacCulloch (2000) "The Determination of Unemployment Benefits", Journal of Labor Economics (forthcoming).

Durham, Y., Hirshleifer, J. and V. Smith (1998) "Do the Rich Get Richer and the Poor Poorer? Experimental Tests of a Model of Power", American Economic Review, 88(4): 970-983.

Ehrenberg, R. and R. Oaxaca (1976) "Unemployment Insurance, Duration of Unemployment and Subsequent Wage Gain", American Economic Review, 66(5): 75466.

Feldstein, M. (1974) "Social Security, Induced Retirement, and Aggregate Capital Accumulation", Journal of Political Economy, 82 (September/October): 905-926.

Feldstein, M. (1976) “Temporary Layoffs in the Theory of Unemployment", Journal of Political Economy, 84(5): 937-957.

Feldstein, M. (1978) "The Effect of Unemployment Insurance on Temporary Layoff Unemployment", American Economic Review, 68(5): 834-46.

Feldstein, M. (1996) “The Missing Piece in Policy Analysis: Social Security Reform”, American Economic Review Papers and Proceedings, 86 (May): 1-14.

Fording, R. (1997) "The Conditional Effect of Violence as a Political Tactic: Mass Insurgency, Welfare Generosity, and Electoral Context in the American States", American Journal of Political Science, 41(1): 1-29.

Francisco, R. (1993) “Theories of Protest and the Revolutions of 1989”, American Journal of Political Science, 37(3): 663-680. 
Garfinkel, M. and G. Skaperdas (1996) The Political Economy of Conflict and Appropriation, edited, New York: Cambridge University Press.

Grossman, H. (1991) “A General Equilibrium Model of Insurrections”, American Economic Review, 81(4): 912-921.

Grossman, H. (1994) "Production, Appropriation and Land Reform", American Economic Review, 84(June): 705-712.

Grossman, H. (1999) “Kleptocracy and revolutions”, Oxford Economic Papers, 51: 267-283.

Grossman, H. and M. Kim (1995) "Swords or Plowshares? A Theory of the Security of Claims to Property", Journal of Political Economy, 103(6): 1275-1288.

Gurr. T. (1970) Why Men Rebel?, Princeton, NJ: Princeton University Press.

Gurr, T. and W. Moore (1997) "Ethnopolitical Rebellion: A Cross-Sectional Analysis of the 1980s with Risk Assessments for the 1990s", American Journal of Political Science, 41(4): 1079-1103.

Haavelmo, T. (1954) A Study in the Theory of Economic Evolution, Amsterdam: North-Holland.

Hicks, A. and D. Swank (1992) "Politics, Institutions and Welfare Spending in Industrialized Democracies, 1960-82”, American Political Science Review, 86: 658-674.

Hirshleifer, J. (1991) “The Technology of Conflict as an Economic Activity", American Economic Review, 81(2): 130-134.

Hirshleifer, J. (1995) "Anarchy and its Breakdown", Journal of Political Economy, 103(February): 26-52.

Hubbard, R. and K. Judd (1987) "Social Security and Individual Welfare: Precautionary Savings, Borrowing Constraints, and the Payroll Tax", American Economic Review, 77(September): 630-646.

Imrohoroglu, A., Imrohoroglu, S. and D. Joines (1995) "A Life-Cycle Analysis of Social Security", Economic Theory 6 (June): 83-114.

Kuran, T. (1991) "The East European Revolution of 1989: Is It Surprising that We Were Surprised?", American Economic Review, 81(2): 121-125. 
Layard, R., S. Nickell and R. Jackman (1991) Unemployment, New York: Oxford University Press.

Lichbach, M. (1987) "Deterrence or Escalation? The Puzzle of Aggregate Studies of Repression and Dissent", Journal of Conflict Resolutions 31: 266-297.

Lichbach, M. (1989) "An Evaluation of 'Does Economic Inequality Breed Political Conflict?' Studies”, World Politics 41(July): 431-470.

Lohmann, S. (1994) "The Dynamics of Informational Cascades: The Monday Demonstrations in Leipzig, East Germany, 1989-91", World Politics 47 (October): 42101.

MacCulloch, R. (1999) “What Makes a Revolution?”, ZEI, University of Bonn Working Paper No. B 24.

Marx, K. (1844) “Contribution to the Critique of Hegel's Philosophy of Right”, in DeutschFranzosische Jahrbucher.

Marx, K. (1887) Das Kapital, Moscow: Progress Publishers.

Moulton, B. (1986) "Random Group Effects and the Precision of Regression Estimates", Journal of Econometrics, 32: 385-397.

Muller, E. (1985) "Income Inequality, Regime Repressiveness and Political Violence", American Sociological Review, 50(February): 47-61.

Nickell, S. (1979) "The Effect of Unemployment and Related Benefits on the Duration of Unemployment", Economic Journal, 89: 34-49.

North, D. (1981) Structure and Change in Economic History, New York: Norton.

North, D. and B. Weingast (1989) "Constitutions and commitment: the evolution of institutions governing public choice in seventeenth-century England", The Journal of Economic History, 49(4).

OECD (1994) The OECD Jobs Study, OECD.

Olson, M. (1965) The Logic of Collective Action, Cambridge: Harvard University Press. 
Oswald, A. (1986) "Unemployment Insurance and Labor Contracts under Asymmetric Information: Theory and Facts", American Economic Review, 76 (June): 365-77.

Perotti, R. (1996) "Growth, Income Distribution and Democracy: What the Data Say", Journal of Economic Growth, 1: 149-187.

Rodrik, D. (1998) “Why Do More Open Economies have Bigger Governments?”, Journal of Political Economy, 106(5): 997-1032.

Roemer, J. (1985) “Rationalizing Revolutionary Ideology”, Econometrica, 53: 85-108.

Roemer, J. (1998) "Why the Poor do not Expropriate the Rich: An Old Argument in New Garb", Journal of Public Economics, 70: 399-424.

Rorer, L. (1965) “The Great Response-Style Myth”, Psychological Bulletin, 63: 129-56.

Rose-Ackerman, S. (1975) “The Economics of Corruption”, Journal of Public Economics, 4 (February): 187-203.

Sala-i-Martin, X. (1997) “Transfers, Social Safety Nets, and Economic Growth", IMF Staff Papers, 44(1): 81-102.

Samuelson, P. (1958) "An Exact Consumption-Loan Model of Interest with or without the Social Contrivance of Money”, Journal of Political Economy, 66 (December): 467-482.

Schelling, T. (1960) The Strategy of Conflict, Cambridge: Harvard University Press.

Schumpeter, J. (1991) "The Crisis of the Tax State", in Joseph A. Schumpeter: The Economics and Sociology of Capitalism, Ed.: Richard Swedberg, Princeton, NJ: Princeton University Press.

Shapiro, C. and J. Stiglitz (1985) "Equilibrium Unemployment as a Worker Discipline Device", American Economic Review, 74(3): 433-444.

Shavell, S. and L. Weiss (1979) "The Optimal Payment of Unemployment Benefits over Time”, Journal of Political Economy, 87(6): 1347-1362.

Shiller, R. (1998) "Social Security and Institutions for Intergenerational, Intragenerational, and International Risk Sharing", NBER Working Paper Series No. 6641. 
Skaperdas, S. (1991) "Conflict and Attitudes Toward Risk", American Economic Review, 81(2): 116-120.

Skaperdas, S. (1992) "Cooperation, Conflict, and Power in the Absence of Property Rights", American Economic Review, 82(4): 720-739.

Tabellini, G. (1990) “A Positive Theory of Social Security”, NBER Working Paper Series No. 3272 .

Tabellini, G. (1991) “The Politics of Intergenerational Redistribution”, Journal of Political Economy, 99 (April): 335-357.

Tarrow, S. (1989) Struggle, Politics and Reform: Collective Action and Politics $\mathbf{2}_{2}$ New York: Cambridge University Press.

Tilly, C. (1978) From Mobilization to Revolution, Reading, MA: Random House.

Tullock, G. (1974) The Social Dilemma: the Economics of War and Revolution, Center for the Study of Public Choice, Fairfax, VA.

Wright, R. (1986) "The Redistributive Roles of Unemployment Insurance and the Dynamics of Voting", Journal of Public Economics, 31: 377-99. 
Table 1.1

Support for Revolution: 12 Countries, 1976 to 1990.

\begin{tabular}{lccccc}
\hline \hline $\begin{array}{l}\text { Support for } \\
\text { Revolt? }\end{array}$ & All & $\begin{array}{c}\text { Unemploye } \\
\text { d }\end{array}$ & Male & $\begin{array}{c}\text { Manual } \\
\text { Workers }\end{array}$ & $\begin{array}{c}\text { Religious } \\
\text { Persons }\end{array}$ \\
\hline Yes & 6.0 & 9.9 & 6.8 & 7.4 & 5.0 \\
No & 94.0 & 90.1 & 93.2 & 92.6 & 95.0 \\
\hline \hline
\end{tabular}

\begin{tabular}{lcc|cccc}
\hline \hline & Partisan & Support & \multicolumn{3}{c}{ Income } & Quartiles \\
\cline { 2 - 7 } $\begin{array}{l}\text { Support } \\
\text { For Revolt? }\end{array}$ & Left & Right & $\begin{array}{c}1^{\text {st }} \\
\text { (Lowest) }\end{array}$ & 2nd & 3rd & $\begin{array}{c}\text { 4th } \\
\text { (Highest) }\end{array}$ \\
\hline Yes & 7.9 & 3.2 & 6.7 & 6.6 & 5.7 & 5.2 \\
No & 92.1 & 96.8 & 93.3 & 93.4 & 94.3 & 94.8 \\
\hline \hline
\end{tabular}

Note: Based on 200,547 observations. All numbers are expressed as percentages.

Table 1.2

Summary Statistics

\begin{tabular}{lccccc}
\hline \hline Variable & Obs. & Mean & $\begin{array}{c}\text { Std. } \\
\text { Dev. }\end{array}$ & Min. & Max. \\
\hline SUPPORT REVOLT & 200,547 & 0.060 & 0.237 & 0 & 1 \\
SOCIAL SECURITY & 154 & 0.180 & 0.046 & 0.092 & 0.288 \\
UNEMPLOYMENT RATE & 154 & 0.087 & 0.037 & 0.003 & 0.220 \\
OUTPUT & 154 & 7,744 & 2,377 & 2,145 & 12,184 \\
UNEMPLOYMENT BENEFITS & 143 & 0.297 & 0.166 & 0.004 & 0.562 \\
\hline \hline
\end{tabular}


Table 2

The Effect of Social Security and Personal Characteristics on Support for Revolt: 12 Countries, 1976-90.

\begin{tabular}{|c|c|c|c|c|c|}
\hline Dependent Var.: Support for Revolt & (1) & (2) & (3) & (4) & (5) \\
\hline Social Securitv & & $\begin{array}{c}-0.294 * \\
(0.130)\end{array}$ & $\begin{array}{c}-0.493 * * \\
(0.145)\end{array}$ & $\begin{array}{c}-0.494 * * \\
(0.138)\end{array}$ & $\begin{array}{c}-0.720 * * \\
(0.294)\end{array}$ \\
\hline Unemployment Rate & & & $0.295 *$ & 0.197 & 0.347 \\
\hline & & & $(0.142)$ & $(0.199)$ & $(0.305)$ \\
\hline Output & & & & $-1.6 e-5$ & $-1.3 e-5$ \\
\hline & & & & $(1.4 \mathrm{e}-5)$ & $(1.8 \mathrm{e}-5)$ \\
\hline Religious & & & & & $\begin{array}{c}-0.053 * * \\
(0.014)\end{array}$ \\
\hline Unemployed & $0.022 * *$ & $0.022 * *$ & $0.022 * *$ & $0.022 * *$ & $0.018 * *$ \\
\hline & $(0.008)$ & $(0.008)$ & $(0.008)$ & $(0.008)$ & $(0.007)$ \\
\hline Male & $0.015 * *$ & $0.015 * *$ & $0.015^{* *}$ & $0.015 * *$ & $0.015 * *$ \\
\hline & $(0.002)$ & $(0.002)$ & $(0.002)$ & $(0.002)$ & $(0.002)$ \\
\hline Self employed & 0.001 & 0.001 & 0.001 & 0.001 & 0.001 \\
\hline & $(0.006)$ & $(0.006)$ & $(0.006)$ & $(0.006)$ & $(0.006)$ \\
\hline Manual Worker & $0.012 * *$ & $0.012 * *$ & $0.012 * *$ & $0.012 * *$ & $0.010 * *$ \\
\hline & $(0.004)$ & $(0.004)$ & $(0.004)$ & $(0.004)$ & $(0.003)$ \\
\hline Income Quartile: Second & $\begin{array}{c}-0.010 * * \\
(0.001)\end{array}$ & $\begin{array}{c}-0.010^{* *} * \\
(0.001)\end{array}$ & $\begin{array}{c}-0.010 * * \\
(0.001)\end{array}$ & $\begin{array}{c}-0.010 * * \\
(0.001)\end{array}$ & $\begin{array}{c}-0.010 * * \\
(0.002)\end{array}$ \\
\hline Third & $-0.019 * *$ & $-0.019 * *$ & $-0.019 * *$ & $-0.019 * *$ & $-0.018 * *$ \\
\hline & $(0.002)$ & $(0.002)$ & $(0.002)$ & $(0.002)$ & $(0.002)$ \\
\hline Fourth (highest) & $-0.024 * *$ & $-0.024 * *$ & $-0.024 * *$ & $-0.024 * *$ & $-0.024 * *$ \\
\hline & $(0.002)$ & $(0.002)$ & $(0.002)$ & $(0.002)$ & $(0.003)$ \\
\hline Age & $-0.001 * *$ & $-0.001 * *$ & $-0.001 * *$ & $-0.001 * *$ & $-0.001 *$ \\
\hline & $(2.0 \mathrm{e}-4)$ & $(2.0 \mathrm{e}-4)$ & $(1.9 e-4)$ & $(1.9 \mathrm{e}-4)$ & $(3.8 \mathrm{e}-4)$ \\
\hline Age Squared & $1.7 \mathrm{e}-6$ & $1.8 \mathrm{e}-6$ & $1.8 \mathrm{e}-6$ & $1.8 \mathrm{e}-6$ & $4.6 e-6$ \\
\hline Education: $\geq 15$ vears $\& \leq 18$ vears & $\begin{array}{l}(1.9 \mathrm{e}-0) \\
-0.001\end{array}$ & $\begin{array}{l}(2.00-0) \\
-0.001\end{array}$ & $\begin{array}{l}(1.9 e-0) \\
-0.001\end{array}$ & $\begin{array}{l}(1.9 e-0) \\
-0.001\end{array}$ & 0.002 \\
\hline 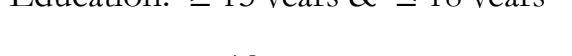 & $(0.002)$ & $(0.002)$ & $(0.002)$ & $(0.002)$ & $(0.002)$ \\
\hline$>18$ years & 0.006 & 0.006 & 0.006 & 0.006 & 0.005 \\
\hline Marital Status: Married & $\begin{array}{c}(0.005) \\
-\mathbf{0 . 0 1 1} * *\end{array}$ & $\begin{array}{c}(0.005) \\
-\mathbf{0 . 0 1 0 * *}\end{array}$ & $\begin{array}{c}(0.005) \\
-\mathbf{0 . 0 1 0 * *}\end{array}$ & $\begin{array}{c}(0.005) \\
\mathbf{- 0 . 0 1 0 * *}\end{array}$ & $\begin{array}{c}(0.004) \\
-\mathbf{0 . 0 0 7} * *\end{array}$ \\
\hline & $(0.002)$ & $(0.002)$ & $(0.002)$ & $(0.002)$ & $(0.003)$ \\
\hline Divorced & 0.011 & 0.011 & 0.011 & 0.011 & 0.011 \\
\hline & $(0.006)$ & $(0.006)$ & $(0.006)$ & $(0.006)$ & $(0.007)$ \\
\hline Separated & $0.022 * *$ & $0.022 * *$ & $0.022 * *$ & $0.022 * *$ & $0.034 * *$ \\
\hline & $(0.006)$ & $(0.006)$ & $(0.006)$ & $(0.006)$ & $(0.008)$ \\
\hline Widowed & $-0.007 * *$ & $-0.007 * *$ & $-0.007 * *$ & $-0.007 * *$ & -0.007 \\
\hline & $(0.002)$ & $(0.002)$ & $(0.002)$ & $(0.002)$ & $(0.004)$ \\
\hline Number of children: 1 & $-4.4 e-4$ & $-4.0 e-4$ & $-4.8 e-4$ & $-4.5 e-4$ & $0.004 * *$ \\
\hline & $(0.002)$ & $(0.002)$ & $(0.002)$ & $(0.002)$ & $(0.002)$ \\
\hline 2 & -0.002 & -0.002 & -0.002 & -0.002 & $4.8 \mathrm{e}-4$ \\
\hline & $(0.003)$ & $(0.003)$ & $(0.003)$ & $(0.003)$ & $(0.003)$ \\
\hline$\geq 3$ & -0.002 & -0.003 & -0.002 & -0.002 & $-8.7 e-5$ \\
\hline & $(0.003)$ & (0.003) & $(0.003)$ & $(0.003)$ & $(0.004)$ \\
\hline Retired & -0.005 & -0.005 & -0.005 & -0.005 & -0.007 \\
\hline & $(0.005)$ & $(0.005)$ & $(0.005)$ & $(0.005)$ & $(0.005)$ \\
\hline Home & 0.002 & 0.002 & 0.002 & 0.002 & 0.003 \\
\hline & $(0.005)$ & $(0.005)$ & $(0.005)$ & $(0.005)$ & $(0.005)$ \\
\hline School & $\begin{array}{c}0.006 \\
(0.006)\end{array}$ & $\begin{array}{c}0.006 \\
(0.006)\end{array}$ & $\begin{array}{c}0.006 \\
(0.006)\end{array}$ & $\begin{array}{c}0.006 \\
(0.006)\end{array}$ & $\begin{array}{c}0.006 \\
(0.007)\end{array}$ \\
\hline Country Dummies & Yes & Yes & Yes & Yes & Yes \\
\hline Year Dummies & Yes & Yes & Yes & Yes & Yes \\
\hline Country Specific Time Trends & Yes & Yes & Yes & Yes & Yes \\
\hline Pseudo $R^{2}$ & 0.048 & 0.049 & 0.049 & 0.049 & 0.067 \\
\hline Observations & 200,547 & 200,547 & 200,547 & 200.547 & 95,035 \\
\hline
\end{tabular}

Notes: [1] Regressions are Probits. [2] Marginal Probabilities (robust standard errors) reported. [3] Bold-face is significant at 10 percent level; Single-starred bold at 5 per cent level; Double-starred bold at 1 percent level 
Table 3

The Effect of Unemployment Benefits as well as Social Security on the Support for Revolt: 12 Countries, 1976 to 1990.

\begin{tabular}{|c|c|c|c|c|c|}
\hline Dep. Var.: Support for Revolt & (1) & (2) & (3) & (4) & (5) \\
\hline Social Securitv & & & & $\begin{array}{c}-0.548 * * \\
(0.117)\end{array}$ & $\begin{array}{c}-0.554 * * \\
(0.099)\end{array}$ \\
\hline Unemplovment Benefits & $\begin{array}{c}-0.187 * * \\
(0.072)\end{array}$ & $\begin{array}{c}-0.189 * * \\
(0.070)\end{array}$ & $\begin{array}{c}-0.234 * * \\
(0.072)\end{array}$ & $\begin{array}{c}-0.207 * * \\
(0.070)\end{array}$ & $\begin{array}{c}-0.254 * * \\
(0.068)\end{array}$ \\
\hline Unemplovment Rate & & $\begin{array}{c}0.103 \\
(0.113)\end{array}$ & $\begin{array}{l}-0.035 \\
(0.165)\end{array}$ & $\begin{array}{c}0.321 * \\
(0.132)\end{array}$ & $\begin{array}{c}0.182 \\
(0.174)\end{array}$ \\
\hline Output & & & $\begin{array}{c}-2.2 e-5 \\
(1.6 e-5)\end{array}$ & & $\begin{array}{c}-2.3 e-5 \\
(1.3 e-5)\end{array}$ \\
\hline Personal Controls & Yes & Yes & Yes & Yes & Yes \\
\hline Countrv Dummies & Yes & Yes & Yes & Yes & Yes \\
\hline Year Dummies & Yes & Yes & Yes & Yes & Yes \\
\hline Countrv Specific Time & Yes & Yes & Yes & Yes & Yes \\
\hline Pseudo $R^{2}$ & 0.048 & 0.048 & 0.049 & 0.049 & 0.049 \\
\hline Ohservations & 195.269 & 195.269 & 195.269 & 195.269 & 195.269 \\
\hline
\end{tabular}




\section{Table 4}

The Effect of Social Security and Unemployment Benefits on the Support for Revolt using Instrumental Variables Estimation: 12 Countries, 1976 to 1990.

\begin{tabular}{|c|c|c|c|c|c|c|}
\hline Dep. Var.: Support for Revolt & (1) & (2) & (3) & (4) & (5) & (6) \\
\hline Social Security & $\begin{array}{c}-1.581 * * \\
(0.538)\end{array}$ & $\begin{array}{c}-1.480 * * \\
(0.562)\end{array}$ & & & $\begin{array}{c}-0.702 \\
(0.367)\end{array}$ & $\begin{array}{l}-0.729 \\
(0.419)\end{array}$ \\
\hline Unemployment Benefits & & & $\begin{array}{l}-0.504 \\
(0.310)\end{array}$ & $\begin{array}{c}-0.817 \\
(0.482)\end{array}$ & $\begin{array}{c}-0.384 * \\
(0.195)\end{array}$ & $\begin{array}{l}-0.335 \\
(0.264)\end{array}$ \\
\hline Unemployment Rate & $\begin{array}{c}0.742 * * \\
(0.274)\end{array}$ & $\begin{array}{c}0.553^{* *} \\
(0.285)\end{array}$ & $\begin{array}{c}0.060 \\
(0.106)\end{array}$ & $\begin{array}{l}-0.214 \\
(0.186)\end{array}$ & $\begin{array}{c}0.361 \\
(0.195)\end{array}$ & $\begin{array}{c}0.178 \\
(0.247)\end{array}$ \\
\hline Output & & $\begin{array}{l}-2.0 e-5 \\
(1.1 e-5)\end{array}$ & & $\begin{array}{c}-4.1 e-5 \\
(2.2 e-5)\end{array}$ & & $\begin{array}{l}-2.6 e-5 \\
(1.5 e-5)\end{array}$ \\
\hline Personal Controls & Yes & Yes & Yes & Yes & Yes & Yes \\
\hline Country Dummies & Yes & Yes & Yes & Yes & Yes & Yes \\
\hline Year Dummies & Yes & Yes & Yes & Yes & Yes & Yes \\
\hline Country Specific Time Trends & Yes & Yes & Yes & Yes & Yes & Yes \\
\hline$R^{2}$ & 0.446 & 0.489 & 0.470 & 0.264 & 0.587 & 0.635 \\
\hline Observations $^{1}$ & 200,547 & 200,547 & 195,269 & 195,269 & 195,269 & 195,269 \\
\hline
\end{tabular}

Notes: [1] All regressions are Two Stage Least Squares. To do them, we first ran probit regressions of the support for revolt on the set of personal characteristics listed in Table 4.1 separately for each country. The coefficients on the year dummies in these regressions were subsequently used as the dependent variable in 2SLS regressions in which Social Security and Unemployment Benefits were instrumented. [2] Bold-face denotes significant at the 10 percent level; Single-starred bold-face at the 5 per cent level; Double-starred bold face at the 1 percent level. [3] Columns (1) and (2) use the proportion of elderly people in the population ( $\geq 65$ years) as an instrument; Columns (3) and (4) use the level and lag of openness as instruments; Columns (5) and (6) use the levels and lags of the proportion of elderly people and openness, as well as the lagged level of the country-specific price of oil to instrument Social Security Generosity and Unemployment Benefits. 


\section{Table 5}

The Effect of Social Security and Unemployment Benefits on the Support for Revolt: Differences Across Sub-groups and Adding More Controls: 12 Countries, 1976 to 1990.

\begin{tabular}{|c|c|c|c|c|c|c|}
\hline & Right & Left & Rich & Poor & All & All \\
\hline Dep. Var.: Support for Revolt & (1) & (2) & (3) & (4) & (5) & (6) \\
\hline Social Security & $\begin{array}{l}-0.181 \\
(0.123)\end{array}$ & $\begin{array}{c}-0.535^{* *} \\
(0.120)\end{array}$ & $\begin{array}{c}-0.642^{* *} \\
(0.109)\end{array}$ & $\begin{array}{c}-0.446 * * \\
(0.126)\end{array}$ & $\begin{array}{c}-0.550 * * \\
(0.096)\end{array}$ & $\begin{array}{c}-0.493 * * \\
(0.105)\end{array}$ \\
\hline Unemployment Benefits & $\begin{array}{l}-0.090 \\
(0.076)\end{array}$ & $\begin{array}{c}-0.270 * * \\
(0.101)\end{array}$ & $\begin{array}{c}-0.176 * * \\
(0.060)\end{array}$ & $\begin{array}{c}-0.337 * * \\
(0.105)\end{array}$ & $\begin{array}{c}-0.247 * * \\
(0.079)\end{array}$ & $\begin{array}{c}-0.195^{* *} \\
(0.075)\end{array}$ \\
\hline Unemployment Rate & $\begin{array}{l}-0.003 \\
(0.125)\end{array}$ & $\begin{array}{c}0.022 \\
(0.162)\end{array}$ & $\begin{array}{c}0.290 \\
(0.207)\end{array}$ & $\begin{array}{l}0.052 \\
0.160\end{array}$ & $\begin{array}{c}0.179 \\
(0.173)\end{array}$ & $\begin{array}{c}0.211 \\
(0.152)\end{array}$ \\
\hline Output & $\begin{array}{c}1.3 e-6 \\
(1.4 e-5)\end{array}$ & $\begin{array}{c}-5.8 e-5 * * \\
(1.5 e-5)\end{array}$ & $\begin{array}{l}-1.1 \mathrm{e}-5 \\
(1.2 \mathrm{e}-5)\end{array}$ & $\begin{array}{c}-3.5 e-5 * \\
(1.5 e-5)\end{array}$ & $\begin{array}{c}-2.4 \mathrm{e}-5^{*} \\
(1.2 \mathrm{e}-5)\end{array}$ & $\begin{array}{l}-1.5 e-5 \\
(1.3 e-5)\end{array}$ \\
\hline Government Consumption & & & & & $\begin{array}{l}-0.061 \\
(0.310)\end{array}$ & $\begin{array}{c}0.079 \\
(0.389)\end{array}$ \\
\hline Right Wing & & & & & & $\begin{array}{c}1.4 e-3 \\
(9.8 e-4)\end{array}$ \\
\hline Military & & & & & & $\begin{array}{l}-0.329 \\
(0.473)\end{array}$ \\
\hline Personal Controls & Yes & Yes & Yes & Yes & Yes & Yes \\
\hline Country Dummies & Yes & Yes & Yes & Yes & Yes & Yes \\
\hline Year Dummies & Yes & Yes & Yes & Yes & Yes & Yes \\
\hline Country Specific Time Trends & Yes & Yes & Yes & Yes & Yes & Yes \\
\hline Pseudo $R^{2}$ & 0.044 & 0.062 & 0.050 & 0.049 & 0.049 & 0.049 \\
\hline Observations & 58,929 & 73,426 & 101,202 & 94,067 & 195,269 & 165,880 \\
\hline
\end{tabular}

Notes: [1] All the regressions are Probits. [2] Marginal Probabilities (robust standard errors) are reported. [3] Bold-face denotes significant at the 10 percent level; Single-starred bold-face at the 5 per cent level; Double-starred bold face at the 1 percent level. 


\section{Appendix: Data Definitions and Survey Descriptions}

\section{Data Definitions}

SUPPORT FOR REVOLT? A dummy variable that equals 1 when the survey respondent answers that "The entire way our society is organised must be radically changed by revolutionary action", and equals 0 when the respondent answers that either "Our society must be gradually improved by reforms" or "Our present society must be valiantly defended against all subversive forces" (Euro-Barometer Survey).

SOCIAL SECURITY: These are transfers to primarily the elderly (pensions) but also include sickness, social assistance grants, family allowances and unfunded employee welfare benefits paid by general Government, measured as a fraction of GDP (OECD Historic Statistics).

UNEMPLOYMENT BENEFITS: Index of (pre-tax) unemployment insurance benefit entitlements divided by the corresponding wage (calculated for oddnumbered years). This summary measure estimates the situation of a representative individual. It calculates the unweighted mean of 18 numbers based on all combinations of the following scenarios: (i) three unemployment durations (for persons with a long record of previous employment); the first year, the second and third years, and the fourth and fifth years of unemployment. (ii) three family and income situations: a single person, a married person with a dependent spouse, and a married person with a spouse in work. (iii) two different levels of previous earnings: average earnings and two-thirds of average earnings (OECD Jobs Study (1994)).

UNEMPLOYMENT RATE: The unemployment rate (CEP OECD Data Set).

OUTPUT: Real GDP per capita at 1985 price levels and exchange rates in U.S. dollars (OECD).

RELIGIOUS: A dummy variable that equals 1 when the survey respondent answers yes to the question "Do you regard yourself as belonging to a religion? If so, which of them". The specific categories of religion listed in the remainder of the question are "1. Catholic 2. Protestant (established Church); Church of England (Britain); Church of Ireland (Ireland, Northern Ireland) 3. Gereformeerd (Netherlands); Church of Scotland (Britain) 4. Non-Conformist, free church (Britain) 5. Other 6. None 7. Greek Orthodox" (Euro-Barometer Survey). 
LEFT/RIGHT: This classification uses the survey question which asks respondents: "If an election were to be held tomorrow, which party would you vote for?". Political scientists subsequently classified the chosen parties into left and right (EuroBarometer Survey).

RICH/POOR: A respondent is classified as "Rich" if they belong to the top two income quartiles and "Poor" otherwise. The quartiles are based on the person's position in their country each year.

GOVERNMENT CONSUMPTION: Government final consumption expenditure as a faction of GDP (CEP-OECD Data Set).

RIGHT WING: Two definitions are used: (i) An index of left/right political party strength equal to the sum of the number of votes received by each party participating in cabinet expressed as a percentage of total votes received by all parties with cabinet representation, multiplied by a left/right political scale constructed by political scientists. Votes are from Mackie and Rose, The International Almanac of Electoral History (1982), cabinet composition from The Europa Yearbook (1969-89) and left/right scale from Castles and Mair (1984). (ii) A dummy variable equal to 1 when a party categorized by political scientists as being "right" is in power. The base category is "left" (see Alesina and Roubini (1992)).

MILITARY: Total military expenditures as a fraction of GDP (Statistical Abstract of the United States and World Military Expenditures and Arms Transfers).

OPENNESS: Total Imports as a fraction of GDP (CEP OECD Data Set).

OIL: An index of the country specific price of oil, obtained by converting the price of oil in US dollars into the local currency and standardizing to equal 1 across all countries in 1975 . 


\section{Survey Descriptions}

The Euro-Barometer Survey Series (1976-1990)

The Euro-Barometer Surveys used in this paper were conducted by various research firms operated within the European Union (E.U.) countries under the direction of the European Commission. Either a nationwide multi-stage probability sample or a nationwide stratified quota sample of persons aged 15 and over was selected in each of the E.U. countries. The cumulative data file used contains 36 attitudinal, 21 demographic and 10 analysis variables selected from the European Communities Studies (1970-1973) and Euro-Barometers (3-38).

Data for Belgium, Denmark, France, Germany, Ireland, Italy, Luxembourg, Netherlands and the United Kingdom were available for the full sample period that was used (1976-1990) whereas data were only available from 1980 to 1990 for Greece and from 1985 to 1990 for both Spain and Portugal. The number of observations in our sample was 18993 for Belgium, 19956 for Britain, 21249 for Denmark, 22366 for France, 21247 for West Germany, 15639 for Greece, 15667 for Ireland, 24476 for Italy, 5278 for Luxembourg, 21873 for The Netherlands, 7218 for Portugal and 6585 for Spain.

The Combined World Values Survey $(1981,1990)$

The Combined World Values Survey is produced by the Institute for Social Research, Ann Arbor, MI, USA. Both national random and quota sampling were used. All of the surveys were carried out through face-to-face interviews, with a sampling universe consisting of all adult citizens, aged 18 and older, across 45 societies around the world. In total there were 379 attitudinal, demographic and analysis variables collected.

Data for The United States, Canada, Mexico, Japan, Argentina, France, Britain, West Germany, Italy, The Netherlands, Denmark, Belgium, Spain, Ireland, South Africa, Hungary, Norway, Sweden, Iceland and Finland were available for both 1980 and 1990. Data for China, Russia, Brazil, Slovenia, Portugal, Poland, Nigeria, Chile, India, Czech-Slovak, East Germany, Bulgaria, Austria, Lithuania, Latvia and Estonia were only available for 1990. Australia was only available for 1980. The number of observations for which data were available for the purposes of the present paper was 3737 for The United States, 2703 for Canada, 2911 for Mexico, 1336 for Japan, 1792 for Argentina, 2057 for France, 2508 for Britain, 3019 for West Germany, 3190 for Italy, 2021 for The Netherlands, 1965 for Denmark, 3297 for Belgium, 5691 for Spain, 2054 for Ireland, 3754 for South Africa, 1153 for Australia, 887 for Hungary, 2324 for Norway, 1790 for Sweden, 1595 for Iceland, 532 for Finland, 958 
for China, 1703 for Russia, 1725 for Brazil, 769 for Slovenia, 989 for Portugal, 855 for Poland, 946 for Nigeria, 1378 for Chile, 2321 for India, 1391 for Czech-Slovak, 1280 for East Germany, 928 for Bulgaria, 1288 for Austria, 932 for Lithuania, 765 for Latvia and 890 for Estonia. 